\title{
O PODER DA IMAGEM ALIADO À FÉ - UM RECORTE A RESPEITO DA CRIATIVIDADE HUMANA A SERVIÇO DA CRENÇA
}

\author{
Diana Krüger Martins - Centro \\ de Artes UFPEL \\ dkmartins90@gmal.com \\ Prof $^{\mathrm{a}}$. Dra . Neiva Maria Fonseca \\ Bohns - Universidade Federal de \\ Pelotas \\ bohnsventos@gmail.com
}

\section{RESUMO}

A presente proposta contempla um recorte de minha monografia de conclusão de curso, ainda em andamento, intitulada "Arte e Religião - Uma dinâmica de experiências". O tema principal aborda o uso de dinâmicas como estratégia de ensino, potencializando o processo artístico. Para tal chegar a tal conclusão, estuda-se a importância da experiência, tanto na vivência artística quanto na religiosa. Sendo assim, no primeiro capítulo intitulado "A criatividade humana a serviço da crença", apontam-se para as associações sobrenaturais com que a humanidade denotou o uso da imagem ao longo dos séculos, até estreitar-se a um panorama que contempla o Cristianismo e sua ramificação protestante. Os principais teóricos utilizados para tal foram BELL (1914) GOMBRICH (1981), CUNHA (2007) e DEWEY (2010).

Palavras-chave: Religião, Arte, História.

\section{INTRODUÇÃO}

A palavra "Religião" tem sua origem no latim "Religare", e significa religar. O termo traz em si a busca por uma re-ligação entre o mundo tangível, secular, profano, e o mundo sobrenatural, espiritual, em que as entidades místicas habitam. Dentro deste sistema, encontra-se uma variedade incontável de práticas, rituais, ensinamentos, mandamentos, cerimônias e liturgias, dedicadas a estabelecer o contato com outro plano. Desde os tempos imemoriais, quando nossos ancestrais passaram a reverenciar o Sol por prover luz e calor, ou temer o poder destrutivo de raios e vulcões, que tal busca pelo transcendente é empreendida pela humanidade. Guerras são travadas entre povos, nações se dividem, templos são construídos e derrubados, pessoas e animais são sacrificados de modos diversos, colheitas e bens materiais são consagrados em troca de bênçãos advindas de um mundo que está além do nosso.

O Sol pode ter sido trocado pela cruz, o sangue substituído pelo dinheiro, e a liturgia sofrido incontáveis mudanças de idioma, porém, a humanidade continua em seu milenar ciclo ritualístico. Há de se concordar que o ser humano é irremediavelmente carente por algo que transcenda o cotidiano, o ordinário e o carnal, e a Religião incorpora esses ideais de forma perfeita. Há de se destacar, no entanto que conceitos tão íntimos do ser humano, envolvendo dúvidas, sentimentos, idealismo e outras questões igualmente complexas também encontram ativação na Arte. De fato, muitos são os que 
acreditam que a Arte possui o mesmo potencial junto à humanidade que a Religião. Bell (1914) afirmou:

\begin{abstract}
A arte e a religião são dois caminhos pelos quais o homem escapa das circunstâncias para o êxtase. Entre o arrebatamento estético e o arrebatamento religioso há um laço familiar. Arte e religião são meios para estados de espírito semelhantes. E, se estivermos autorizados a por de lado a ciência e a estética e, seguindo as nossas emoções e o seu objeto, considerarmos o que está na mente do artista, podemos dizer, com um certo à vontade, que a arte é uma manifestação do sentido religioso. (BELL, 1914, pg.93)
\end{abstract}

$\mathrm{Na}$ verdade, mesmo que a Arte e a Religião tenham se repartido em campos independentes quando a criatividade humana passou a atender a outros objetivos senão o da fé, não se pode negar que por muito tempo, ambas foram praticamente indissociáveis e ainda hoje caminham juntas.

Partindo do objetivo de investigar esta ligação mantida através dos séculos, este artigo apresenta fragmentos presentes em minha monografia de conclusão de curso, onde sob o título "Arte e Religião - Uma dinâmica de experiências" abordo a importância da experiência, tanto no fazer artístico quanto no religioso, para ao final, sugerir a prática de dinâmicas em grupo como metodologia de ensino. Sendo assim, este trabalho de caráter bibliográfico se baseia no primeiro capítulo, chamado "A criatividade humana a serviço da crença", onde busco explorar as características transcendentais com as quais a humanidade dotou a Arte em seus mais diversos suportes e técnicas, especificando a situação do Cristianismo, com destaque para sua ramificação protestante.

Diferentes técnicas, suportes e motivações serão tratadas neste artigo, procurando levarem-se em conta variados contextos sociais, históricos e geográficos envolvidos no processo criativo por motivações religiosas. Para o devido embasamento, trago as colocações de alguns estudiosos que cobrem a área artística, religiosa, histórica e social. Primeiramente são úteis as contribuições de Ernst Gombrich (1981), que a partir de sua famosa obra "A História da Arte", apresenta o fazer criativo utilizado pela humanidade como veículo à crença. John Dewey (2010), por sua vez, em "Arte como experiência" aborda o impacto sensorial e emocional da Arte unida à Religião, juntamente com Clive Bell (1914) em "Arte". Por fim, uma importante contribuição a esta pesquisa, no que tange a um olhar mais acurado sobre o panorama evangélicoprotestante, se encontra nos estudos de Magali do Nascimento Cunha (2007). As considerações da autora, presentes em sua monografia, mais tarde publicada como livro, chamada "A Explosão Gospel” aborda as estratégias artísticas adotadas por lideranças evangélicas e seus resultados, se transfigurando em um interessante material de estudo sobre a situação atual.

\title{
A CRIATIVIDADE HUMANA A SERVIÇO DA CRENÇA
}

Consideremos um aspecto marcante, que segundo o historiador e pesquisador Ernst Hans Gombrich (1909-2001), constitui um ponto fundamental na relação do ser humano com a arte: o poder da imagem. Segundo Gombrich (1981), a arte produzida nos primórdios da humanidade não possuía os propósitos de contemplação, questionamento, ou reflexão presentes na nossa era atual, mas estava fortemente atrelada a objetivos ritualísticos. O ser humano, então, usava de suas habilidades criativas na produção de ícones que o auxiliariam junto ao mundo intangível, como um elo entre a realidade natural e a espiritual. Para os povos pré-históricos, por exemplo, a 
imagem era um recurso poderoso a ser usado a serviço da crença, podendo-se citar a pintura rupestre: a figura de um animal pintada na parede possuía propósitos mágicos, ligados à caça e ao sustento.

Ao abordar as artes visuais, Gombrich (1981) indica o uso de pinturas, máscaras e esculturas que revestidas de aspecto cerimonial, serviam de veículo para a comunhão do ser humano com o lado espiritual, inclusive afirmando a persistência dessas práticas através dos séculos e das mais diversas civilizações. $O$ autor destaca que $o$ conhecimento necessário no feitio de cada peça encontra-se dotado de profundo significado sob o qual existem analogias que subsistem até os dias atuais, ligando a criatividade às crenças.

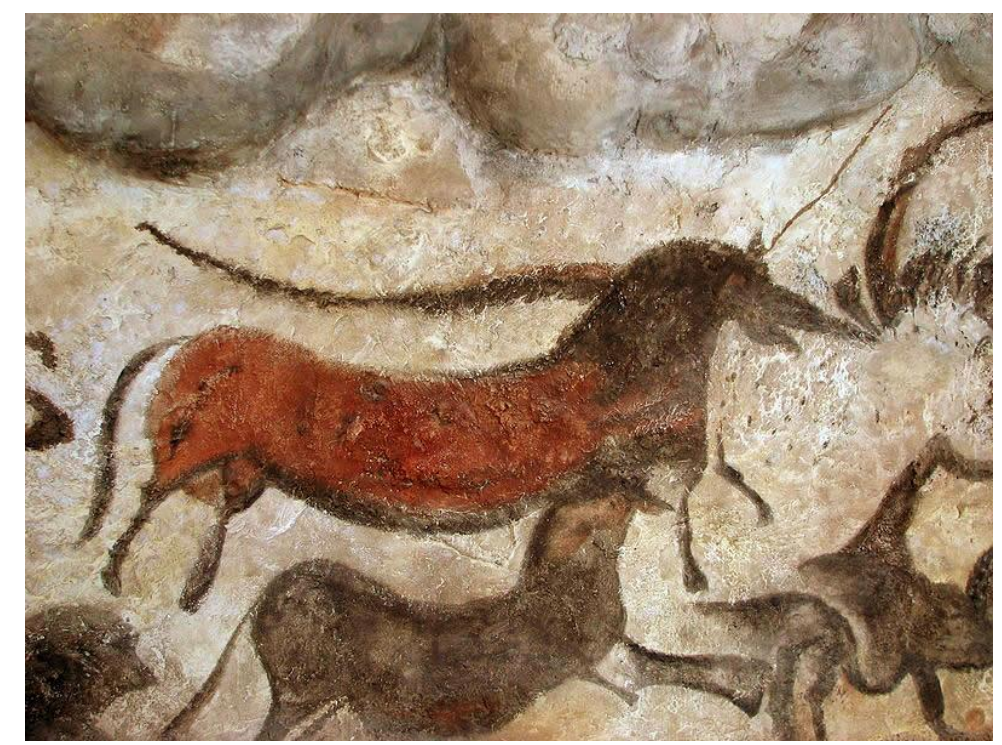

Figura 01 - Animais pintados na caverna de Lascaux, Montignac, França - cerca de 15.000 anos atrás. Fonte: http://www.historiadigital.org/

Um exemplo importante consta na arte egípcia, visto que os esforços monumentais empreendidos na construção de pirâmides, esculturas, sarcófagos e murais cobertos de hieróglifos continham em si a busca pela preservação da imagem daquele que os ordenou. Gombrich (1981) afirma:

Os egípcios sustentavam a crença de que a preservação do corpo não era bastante. Se a fiel imagem do rei também fosse preservada, não havia dúvida alguma de que ele continuaria vivendo para sempre. Assim, ordenavam aos escultores que esculpissem a cabeça do rei em imperecível granito e a colocassem na tumba onde ninguém a via, para aí exercer sua magia e ajudar sua alma a manter-se viva na imagem e através desta. Uma expressão egípcia para designar o escultor era, realmente, "Aquele que mantém vivo". No começo, esses ritos eram reservados aos reis, mas logo os nobres da casa real passaram a ter seus túmulos menores agrupados em filas bem alinhadas em torno do túmulo do rei; e, gradualmente, toda pessoa que se prezava tinha que tomar providências para a vida no além, encomendando uma dispendiosa tumba que abrigasse sua múmia e sua imagem, e onde sua alma pudesse habitar 
e receber as oferendas de alimento e bebida que eram feitas ao morto. (GOMBRICH, 1950, pg.25)

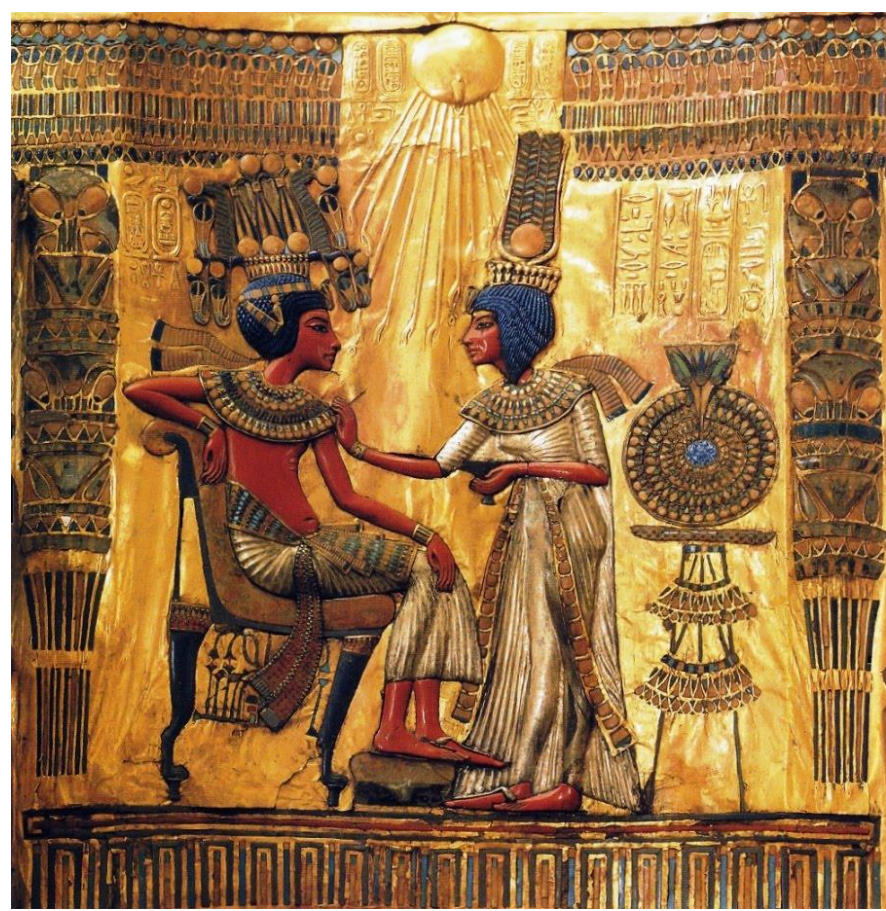

Figura 02 - Faraó Tutankhamen e sua esposa Ankhesenamon. Talha dourada e pintada. Cerca de 1350 a.C. Museu da Cidade do Cairo. Fonte: http://jdecod.blogspot.com.br/

O temor e a inspiração que envolviam a divindade também chegavam até o fiel através da Arte. Há de se destacar também o papel fundamental da arte grega. Pode-se mencionar o escultor Fídias como um dos primeiros nomes em destaque que subsistem pela posteridade. Embora nenhuma de suas obras tenha sobrevivido ao tempo, relatos a respeito da magnificência de sua arte chegaram até nós, uma em especial apresentava especial exuberância: a Athenas Parténos. Sendo seu nome traduzido como Atena Virgem, a estátua contava com doze metros de altura, e tinha a estrutura de madeira revestida em materiais preciosos: a pele em marfim e as vestes e acessórios em ouro. Também possuía olhos feitos com pedras preciosas. Animais como serpentes e cavalos, além de grifos, decoravam o elmo e o escudo da deusa, que estava instalada dentro do templo Partenon, na cidade a qual era padroeira, Atenas. Hoje em dia, podemos contar apenas com cópias em tamanho reduzido, além de relatos de sua descrição, porém é impossível não concluir que a obra inspirava grande temor e reverência em qualquer pessoa que a vislumbrasse. 


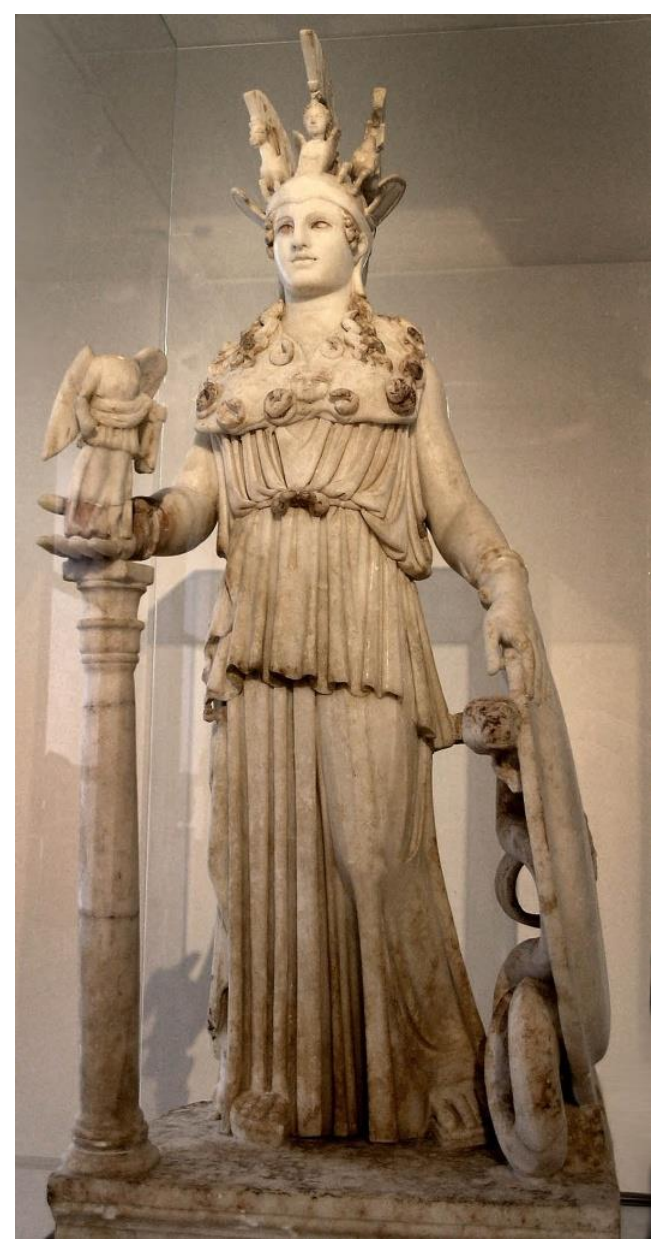

Figura 03 - A Atena Varvakeion, cópia reduzida da Atena Partenos. Museu Arqueológico Nacional de Atenas. Fonte: pt.wikipedia.org/wiki/Atena_Partenos

O poder da imagem também se encontra no uso da Arte como ferramenta propiciadora, ou seja, que auxilia seus fies a alcançarem determinado objetivo, geralmente ligado à proteção ou ao movimento de forças invisíveis, pode ser citado como uma motivação poderosa. Podem-se mencionar os Budas de Bamiyan, que infelizmente foram destruídos pelo grupo fundamentalista islâmico Talibã, em março de 2001. Ambas as estátuas, uma com 55 metros de altura e outra com 38, esculpidas diretamente na rocha, entre os séculos IV e V, são até hoje consideradas os maiores exemplares de Budas em pé e têm a autoria atribuída a monges que viviam nos arredores. Por muito tempo, ambas as estátuas serviam como sentinelas a seus habitantes próximos. Também há de se destacar o Grande Buda de Leshan, que com 71 metros de altura, é considerada a maior estátua de Buda do mundo, e está situada num desfiladeiro próximo à confluência dos rios Minjiang, Dadu e Qingyi, no sul da província de Sichuan, República Popular da China. É interessante notar que o objetivo por trás da construção, iniciada no ano 713, por um monge chamado Haitong, estava ligada à proteção dos barcos que costumavam naufragar ao passarem pelo local de águas turbulentas. Sendo assim, mais uma vez, usa-se de criatividade, habilidade e técnicas humanas, de forma a construir um ícone ligado à crença, que favorecerá seus fiéis de determinada forma. 


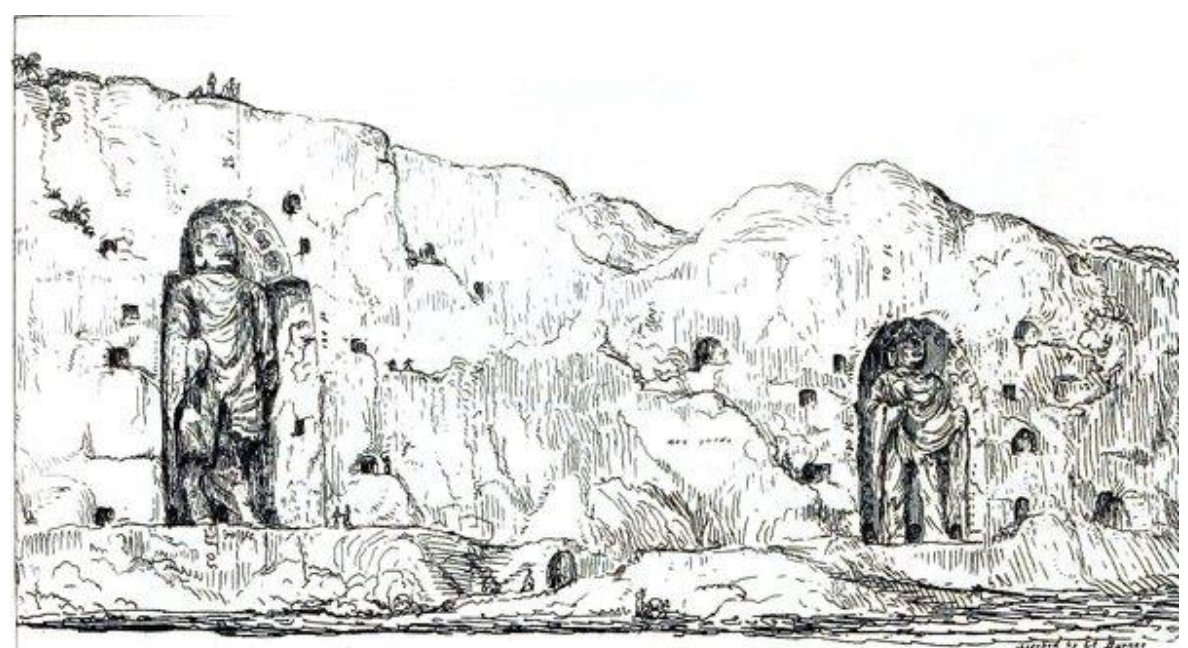

The Colossal Idols, or Buts, of Bamian.

Figura 04 - Ilustração mostrando os dois Budas de Bamiyan, Sir Alexander Burnes, 1833. Fonte: http://lounge.obviousmag.org/

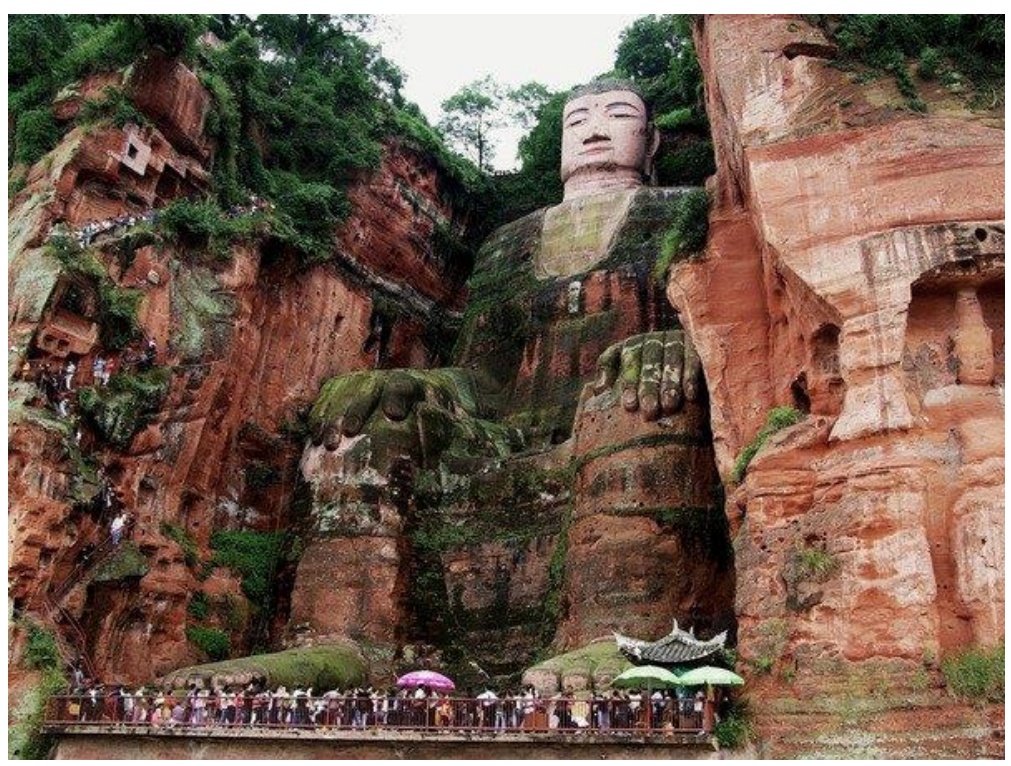

Figura 05 - O Buda de Leshan, província de Sichuan, República Popular da China. Fonte: http://arquiteturadosagrado.blogspot.com.br/

As palavras de Dewey (2010) a respeito do impacto emocional da Arte em sua união com a fé, que embora se refiram à adoção das mais diversas modalidades artísticas a serviço da Igreja Católica durante a Idade Média, também podem ser aplicadas às mais variadas crenças através do tempo:

A música, a pintura, a escultura, a arquitetura, o teatro e o romance eram servos da religião, tanto quando o eram a ciência e a erudição. As artes mal chegavam a ter existência fora da Igreja, e os ritos e cerimônias eclesiásticos eram artes encenadas em condições que lhes davam o máximo possível de apelo emocional e imaginativo. Não sei o que daria ao espectador e ouvinte da manifestação das artes uma entrega mais pungente do que a convicção de que 
elas estavam impregnadas dos meios necessários da glória e da bemaventurança eternas. (DEWEY, 2010,p.102)

Mais tarde, estes mesmos artifícios emocionais se tornariam ainda mais evidentes com o surgimento do Barroco. Este estilo originou-se na Itália, entre o final do século XVI e metade do século XVII, tendo mais tarde se espalhado para outros países católicos da Europa e América, até alcançar países protestantes e alguns pontos do Oriente. Contrariando a harmonia e a leveza renascentista (marcada pela precisão matemática presente em suas composições), o Barroco buscava a intensidade e o apelo emocional, a perfeição anatômica aliada ao movimento, para isso utilizando-se do máximo de expressividade. A igreja Católica, que por séculos foi uma potência poderosa no mundo ocidental, perdia fiéis por conta da Reforma Protestante ${ }^{1}$ e por outros movimentos dentro dela própria ${ }^{2}$, que criticavam a corrupção instalada naquele meio. Sendo assim, o corpo eclesiástico passou a investir no poder da arte para atrair mais fiéis e não sofrer outras perdas. A idéia estava em ornar as igrejas com o máximo de impacto visual, impressionando os crentes através de ricas pinturas (também chamadas de afrescos), esculturas detalhistas e dramáticas, altares revestidos em ouro, e toda uma atmosfera monumental que trataria tanto de manter os fiéis já familiares, quanto de conquistar novos.

Em matéria de escultura, pode-se citar como obra marcante deste período $O$ Extase de Santa Teresa, esculpida em mármore entre os anos de 1645 a 1652, por Gian Lorenzo Bernini (1598-1680). A peça, rica em expressão e dramaticidade, representa a Santa Teresa de Ávila (canonizada em 1622 e fundadora da Ordem das Carmelitas Descalças), sendo atingida no coração por uma flecha do Anjo do Amor Divino. O que mais chama atenção são os detalhes, tanto das expressões nos rostos das figuras, quanto na textura das vestes e nuvens, mostrando o nível da habilidade do artista.

A pintura também era usada de forma ostensiva a serviço da religião, sendo os afrescos (nome dado a uma obra pictórica, feita sobre base de gesso ou argamassa) largamente empregados na ornamentação de igrejas, catedrais e basílicas. A técnica apresenta grande resistência ao tempo e já era utilizada pelos gregos e romanos, para retratarem sua própria mitologia, além de aspectos cotidianos. Porém, foi através da igreja católica que esta arte floresceu e se desenvolveu em seus detalhes mais complexos, apresentando ao mundo grandes nomes, como Giotto (1266-1337), Masaccio (1402-1428), Luca Signorelle (1441-1523), Michelangelo (1475-1564) e Giovanni Tiepollo (1696-1770). E foi no período Barroco que os afrescos ganharam status monumental, quando a Igreja Católica decidiu que seus templos seriam decorados da forma mais impactante possível.

A complexa obra executada no teto da Igreja de Santo Inácio de Loyola, em Roma, intitulada A Glorificação de Santo Inácio, certamente é digna de nota. Realizada pelo jesuíta Andrea Pozzo (1642-1709) entre os anos de 1691 e 1694, a pintura apresenta como tema as obras de Santo Inácio e da Companhia de Jesus, levando a

\footnotetext{
${ }^{1}$ Movimento deflagrado por Martinho Lutero (1483 -1546),monge agostiniano, ao discordar publicamente da prática de venda de indulgências (perdão dos pecados) estabelecida pelo Papa Leão X (1478 - 1521). Lutero protestou com 95 teses que afixou na porta da igreja de onde era pregador, o que ocasionou sua excomunhão e subsequente perseguição resultando em um período de exílio, que usou para traduzir a Bíblia do latim para o alemão.

${ }^{2}$ John Wycliffe (1328 -1384), Jan Huss (1369 -1415), Girolamo Savonarola (1452 - 1498) e Wessel Gansfort (1419-1489), são alguns dos nomes que se configuram como pré-reformadores, protestando contra práticas da Igreja Católica.
} 
glória de Deus até os quatro continentes conhecidos na época, cada um deles representado por uma alegoria. Através de truques envolvendo luz, sombra, ilusão de profundidade e volume, o artista criou uma peça monumental, que praticamente abre o teto da igreja e permite aos crentes um vislumbre do Paraíso e da glória de Deus.

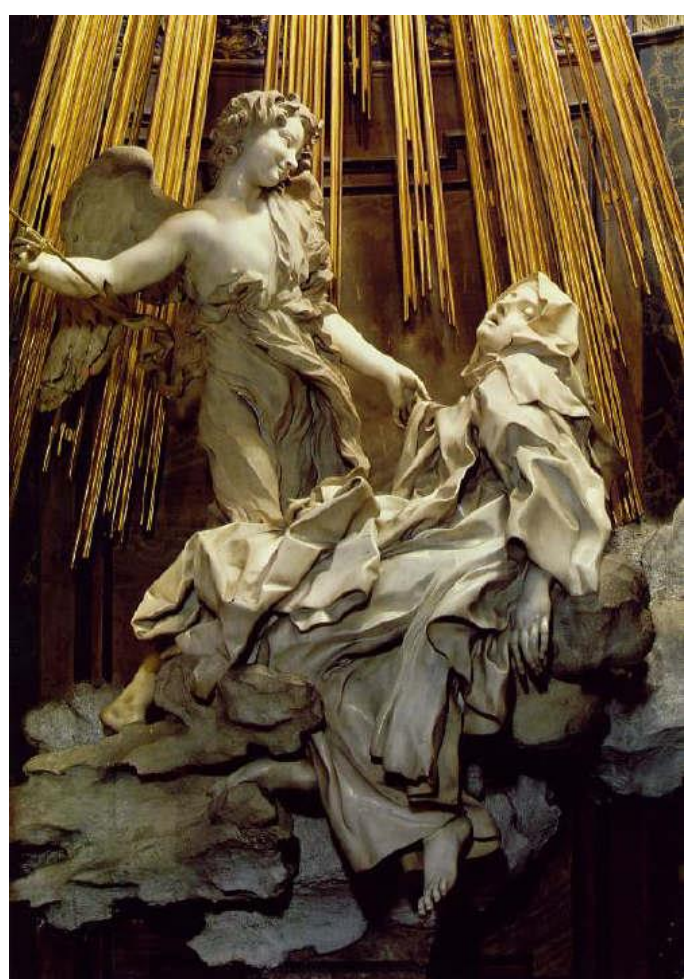

Figura 06 - O Êxtase de Santa Teresa, Gian Lorenzo Bernini, mármore, Capela Cornaro. Santa Maria della Vittória, Roma. Fonte: multiplosestilos.blogspot.com.br

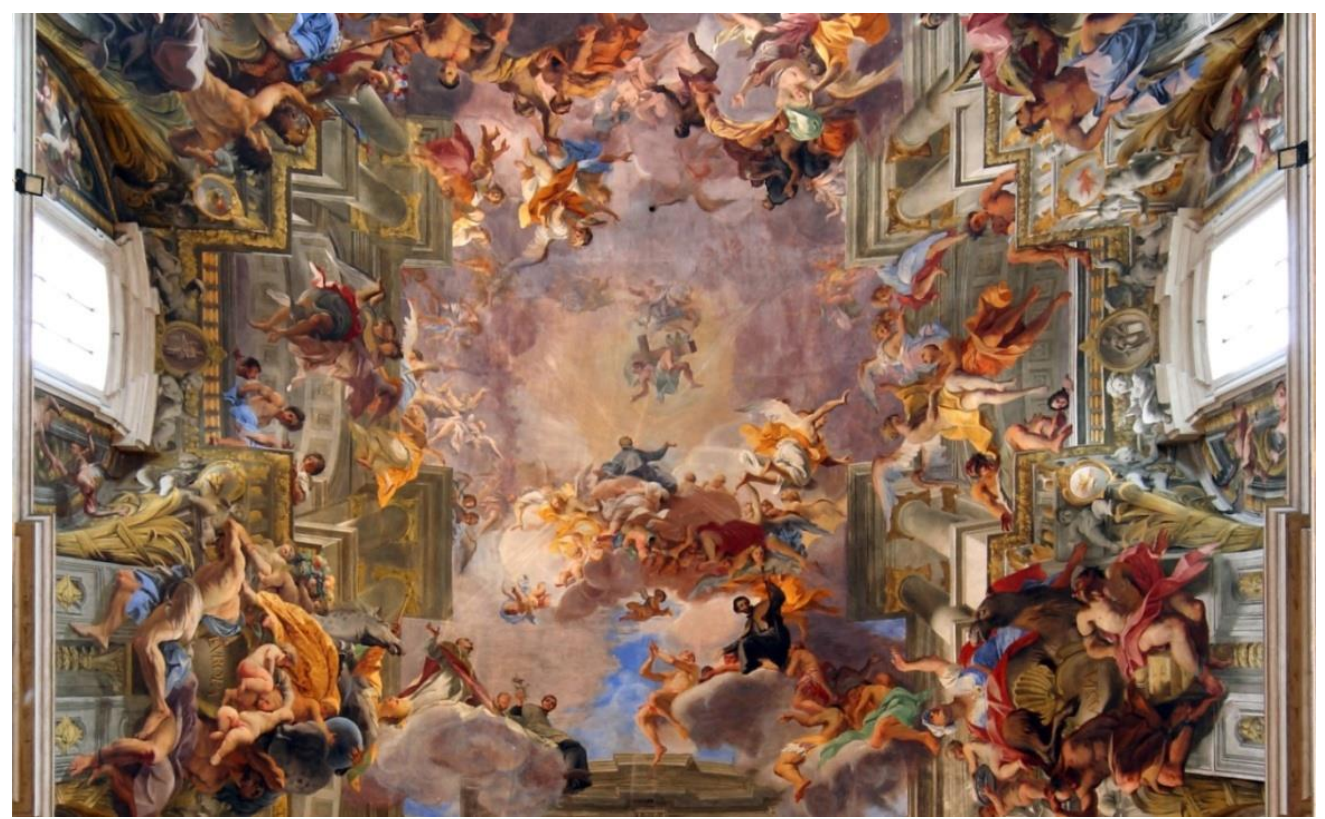

Figura 07 - A Glorificação de Santo Inácio, Andrea Pozzo, afresco, Igreja de Sanro Inácio, Roma. Fonte: pt.wikipedia.org 
Mesmo com todas as mudanças sociais, econômicas e ideológicas através dos séculos, as artes visuais continuaram a ser veículo para as mais diversas crenças. $\mathrm{O}$ advento da tecnologia trouxe-as inclusive para as mídias contemporâneas, como a TV e o cinema. Alguns exemplos a serem apontados encontram-se no clássico "Os Dez Mandamentos" (The Ten Commandments, Cecil B. DeMille, 1956), que relata a história do personagem bíblico Moisés, em sua saga para libertar o povo hebreu da escravidão imposta pelos egípcios, e também o filme indiano Mahabharata (Mahabharat, Babubhai Mistri, 1965), baseado em um texto do Hinduísmo, o Mahabharata. Considerado o texto sagrado mais importante da religião hindú, é também tido como o maior poema de todos os tempos, contando com 200.000 versos. Trata-se de uma obra voltada ao autoconhecimento e a relação da criação natural com tudo aquilo que a transcende.

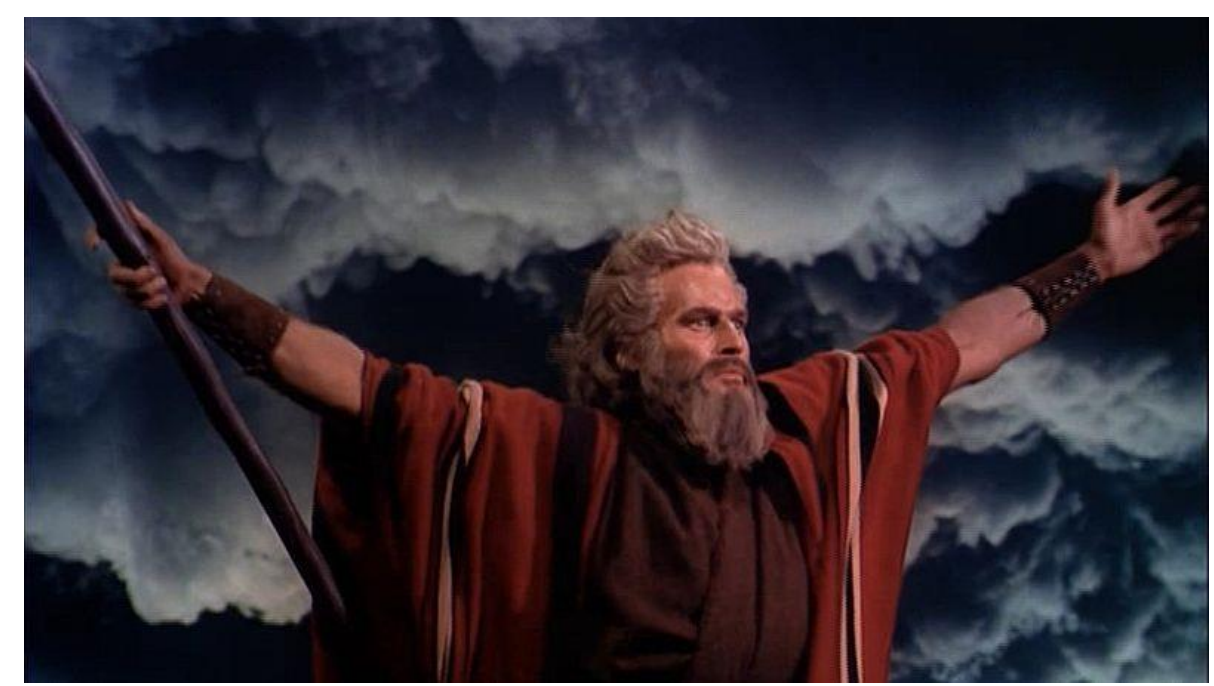

Figura 08 - Cena de "Os Dez Mandamentos” (The Ten Commandments, 1956). Fonte: www.turnbacktogod.com

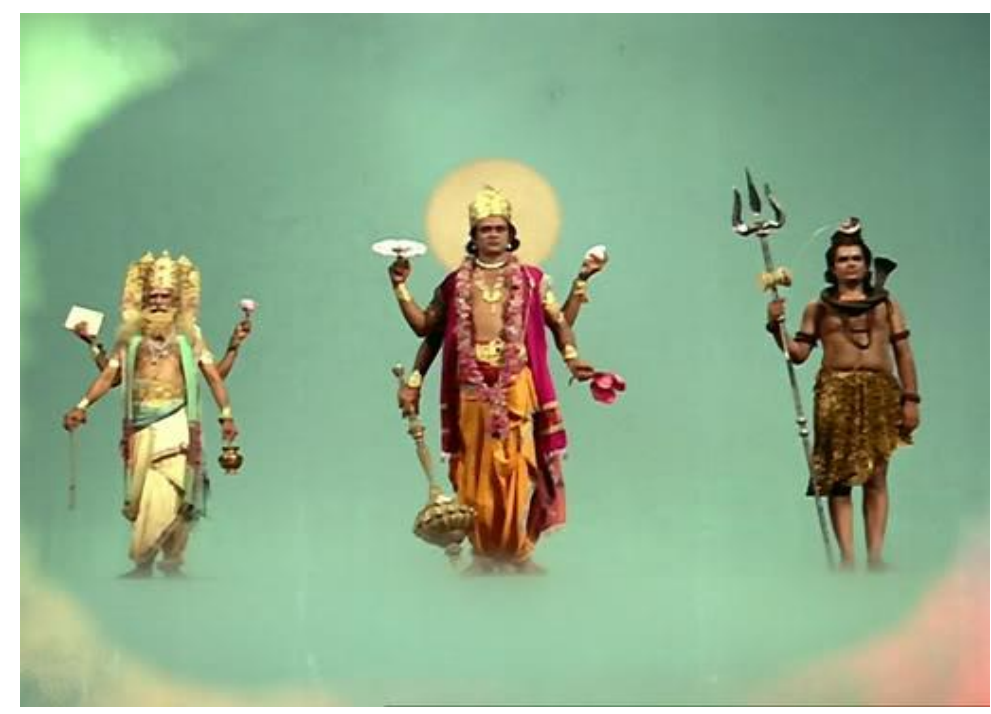

Figura 09 - Cena de "Mahabharata" (Mahabharat,1965). Fonte:www.piratebay.com 
Dewey (2010) faz uma interessante colocação a respeito da capacidade da crença em se manter através dos séculos com o auxílio da narrativa visual aliada a fatores emocionais:

\begin{abstract}
Mas o prazer com a narrativa, com o aumento e a exposição de uma boa história desempenhou então seu papel dominante, tal como faz hoje no crescimento das mitologias populares. Não só o elemento sensorial direto - e a emoção é uma modalidade do sentir - tende a absorver todo o conteúdo ideativo, como também, à parte uma disciplina especial, imposta por um aparato físico, subjuga e digere tudo o que é meramente intelectual. (DEWEY,2010, p.101)
\end{abstract}

Não se pode negar que a arte tem profunda ligação com a crença, e que mesmo passando por adaptações através dos séculos, ambas continuam relacionadas de forma intrínseca no que tange ao desejo humano pela espiritualidade e transcendência. É interessante notar, que embora mantendo em seu núcleo os preceitos originais, a Religião também se molda para o encaixe nas mais diversas mídias, em busca de públicos diferenciados. Como um exemplo a esse processo, vale citar as mudanças ocorridas na difusão do Cristianismo, em especial, ao seu segmento protestante.

\title{
Cristianismo, Protestantismo e as modificações através do tempo
}

Anteriormente, foi dito que a relação entre arte e religião está à mercê das mudanças sociais que o passar do tempo impõe. Sendo assim, mesmo que alguns líderes prefiram negar, é preciso admitir que o exercício da fé cristã encontra-se em constante mutação para melhor atender às demandas de cada geração de fiéis que se propõem a integrar o rebanho. Templos são modificados, liturgias são modernizadas e a própria Bíblia ganha traduções mais acessíveis ao público vigente, ou seja, mesmo que algumas características do passado sejam conservadas, o Cristianismo recebe novas roupagens em sua busca por novos convertidos e a Arte tem papel fundamental neste ato interminável de evangelismo. Seus desdobramentos se fazem presentes atualmente, através de uma curiosa amálgama envolvendo linguagens contemporâneas mescladas com conceitos tradicionais, e através de um olhar mais acurado, seu hibridismo cultural acaba por fornecer um interessante material de pesquisa, envolvendo variados suportes artísticos que agem como chamariz às gerações mais novas.

Juntamente com o Judaísmo e o Islamismo, o Cristianismo é considerado uma das três maiores religiões do mundo ocidental. Ainda que guardando certos pontos principais de seu corpo de crenças, algumas práticas, valores e demais atributos não passaram incólumes através do tempo.

Desde seu surgimento como uma obscura seita judaica do século I, na localidade da Galiléia, região da Palestina, através dos anos de perseguição durante o império de Nero (37-68 d.C.) entre 54 - 68 d.C; até o seu estabelecimento em 313 d.C. por Constantino (272-337 d.C.) como uma força do estado, sendo consolidada por Teodósio (346-395 d.C.) através do Édito de Tessalônica ${ }^{3}$ no ano de 380 d.C., chegando

\footnotetext{
${ }^{3}$ O Édito de Tessalônica ( também conhecido como Cunctos Populos ou De Fide Catolica) foi decretado pelo imperador romano Teodósio I a 27 de fevereiro de 380 d.C pelo qual estabeleceu que o cristianismo tornar-se-ia, exclusivamente, a religião de estado, no Império Romano, abolindo todas as práticas politeístas dentro do império e fechando templos pagãos.
} 
finalmente na sua assimilação pelo Império Romano e subseqüente expansão pelo mundo, a fé baseada nos ensinamentos de Jesus de Nazaré, impactou a humanidade de maneira colossal.

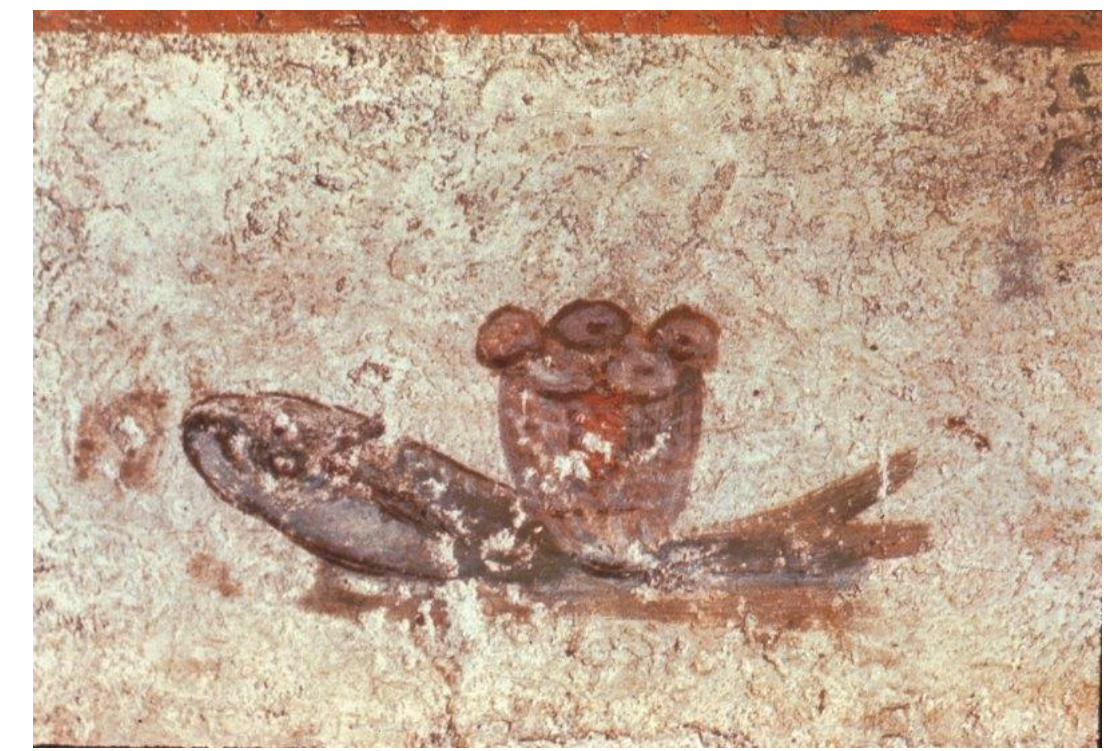

Figura 10 - Pão e peixe eucarísticos, catacumba de São Calisto, Roma. Fonte: pt.wikipedia.org

Hoje em dia podemos ter um panorama privilegiado com relação ao seu legado e iconologia através da história da Arte. Junto com os inúmeros desdobramentos, expansões geográficas e mudanças ideológicas que sofreu ao longo dos séculos, a crença cristã chegou à era contemporânea contando com imenso repertório imagético. Possuímos acesso, desde os registros milenares encontrados nas catacumbas de Roma, denominados de Arte Cristã Primitiva (Arte Paleocristã), passando pela influência grega nos primeiros estatuários, até a visão monumental das catedrais góticas, sem esquecer a precisão matemática dos quadros renascentistas, e da impactante arte barroca.

A relação da fé protestante com a Arte tem passado por intensas transformações ocasionadas por uma complexa rede de acontecimentos resultante do contexto históricosocial de cada época. Segundo Francys Shaeffer ${ }^{4}$ (2010) o valor da Arte advém do fato de o trabalho criativo ser um reflexo do divino, e que desfrutar da mesma não se configura como pecado, porém, certas diretrizes devem ser seguidas no meio. Se por um lado, diferentes modalidades artísticas foram avaliadas com desconfiança, chegando a ser consideradas como práticas heréticas, por outro, também encontraram difusão no ambiente evangélico através de um constante processo de assimilação fundamentado sobre as correntes teológicas existentes em cada local. Variadas linguagens, suportes, esquemas litúrgicos e expressões criativas foram lentamente integrados dentro do cerimonial, ganhando o status de "arte gospel" direcionados à adoração, tendo seu discurso imbuído da mentalidade cristã vigente de cada denominação.

Michael Card (2008), músico e autor cristão, afirma a importância das artes junto aos fiéis, incentivando as práticas criativas como uma espécie de comunhão:

${ }^{4} 1912$-1984 .Teólogo evangélico, pastor presbiteriano e filósofo. 
Se aquilo que criamos, escrevemos, dançamos ou cantamos pode abrir tamanho espaço no tempo por meio do qual Deus pode falar, imagine as possibilidades! A pintura pode tornar-se uma janela através da qual um mundo confuso olha e vê a ordem sadia da criação de Deus. A música pode tornar-se um eco orquestrado da voz que os ouvidos cansados da humanidade há séculos têm ansiado ouvir. Essa é arte por meio da qual Deus é visto e ouvido, na qual Ele é encarnado, é "detalhado" em pintura e tinta, em pedra, em movimento criativo. (CARD , 2008, p.18-19)

Sendo assim, a Arte passa a fazer parte da cultura cristã contemporânea, desdobrando-se em diferentes expressões que vão além do campo musical.

Tratando-se das artes visuais, pode-se apontar sua utilização não apenas no campo evangelístico, mas também como um interessante componente dentro do cenário cultural evangélico-protestante: em lugar dos clássicos afrescos, o maior veículo para tal se encontra em publicações voltadas aos crentes, tanto digitais, quanto físicas. Acreditase que a razão se deve à difusão dos meios de produção gráfica em série, além da fácil distribuição do material, seja através da internet ou de mídias mais tradicionais, como revistas, folhetos e até histórias em quadrinhos. Cunha (2007) aborda esta questão da secularização do discurso evangélico através de novas mídias:

Portanto, os programas e a literatura da mídia evangélica tornam-se os mediadores de uma comunidade de consumidores em que a vinculação religiosa e o consumo de bens e de cultura que possibilitem aproximação com Deus e entretenimento "sadio". Este é o apelo evangélico em tempos de cultura gospel. (CUNHA, 2007, p.205).

Exemplos interessantes a serem apontados se mostram nos trabalhos da artista Pat Marvenko Smith, conhecida por suas elaboradas ilustrações que retratam passagens bíblicas, com destaque para os quarenta trabalhos que narram o livro de Apocalipse. Suas obras são amplamente divulgadas por inúmeras denominações cristãs atuais, que encontram em sua dramaticidade e complexidade um meio para disseminar suas doutrinas. 


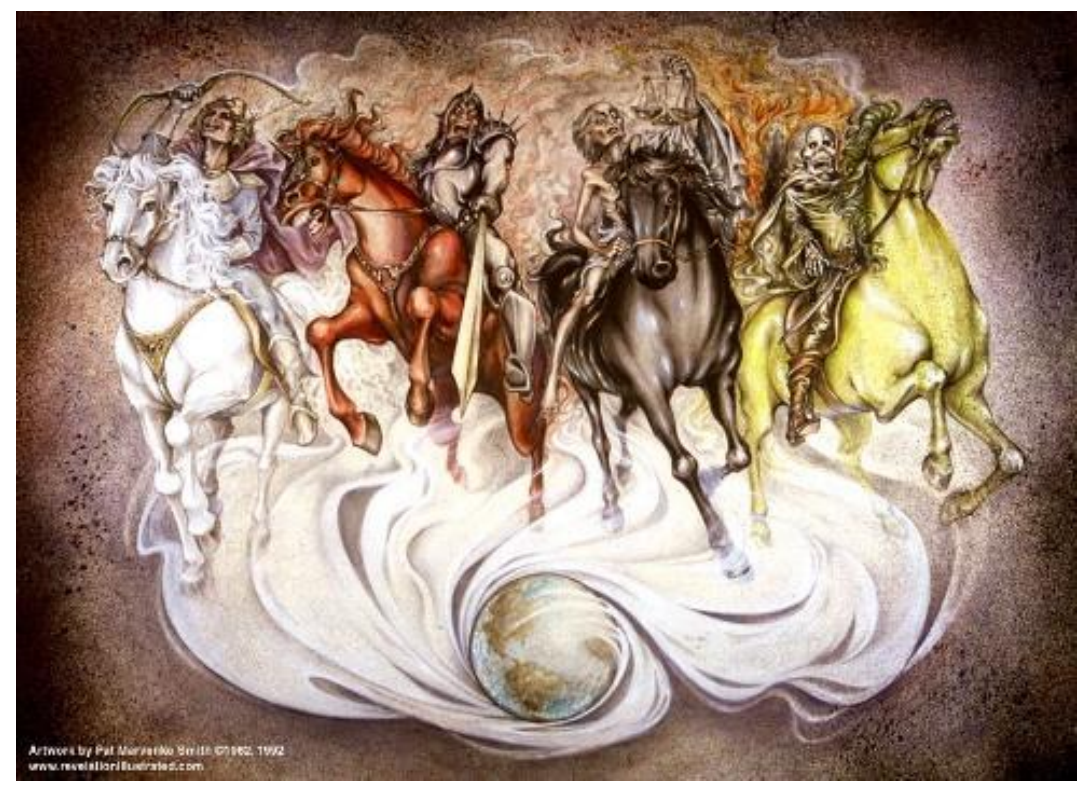

Figura 11 -The First Four Seals; Four Horsemen (Rev. 6:1-8), Pat Marvenko. Fonte: www.chronologicalbibleblog.com

As narrativas bíblicas também se fazem presentes de modo mais palatável às gerações mais jovens através das histórias em quadrinhos. Suas passagens ganham nova dimensão quando trabalhadas por artistas como Chris Koelle e Sergio Cariello . Ambos os ilustradores contam como exemplos no que tange á utilização da criatividade ligada à difusão da crença e se tornam especialmente interessantes quando analisados junto às tendências modernas que buscam meios de divulgação alternativos voltados a um público jovem e acostumado a uma linguagem mais dinâmica e moderna.

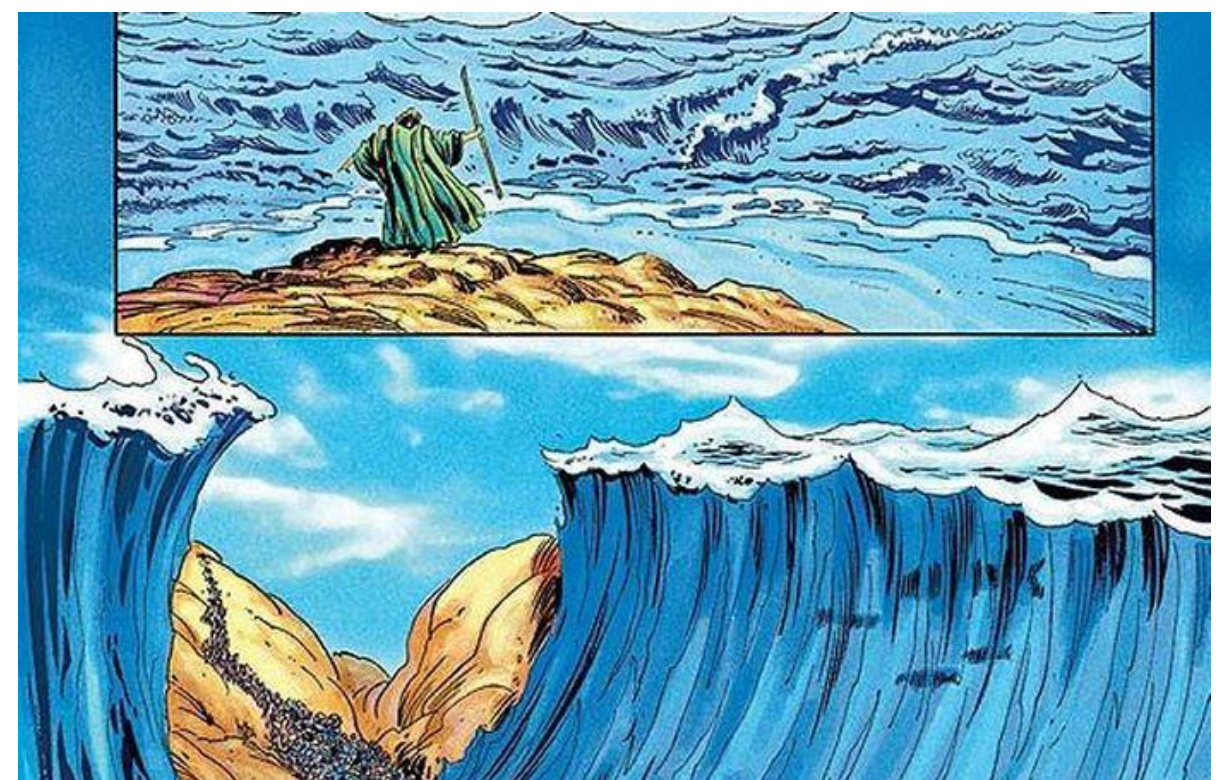

Figura 12 - Moisés abre o Mar Vermelho, trecho de A Bíblia em Ação, Sergio Cariello, 2010, técnica mista.

Fonte: http://sergiocariello.blogspot.com.br/ 


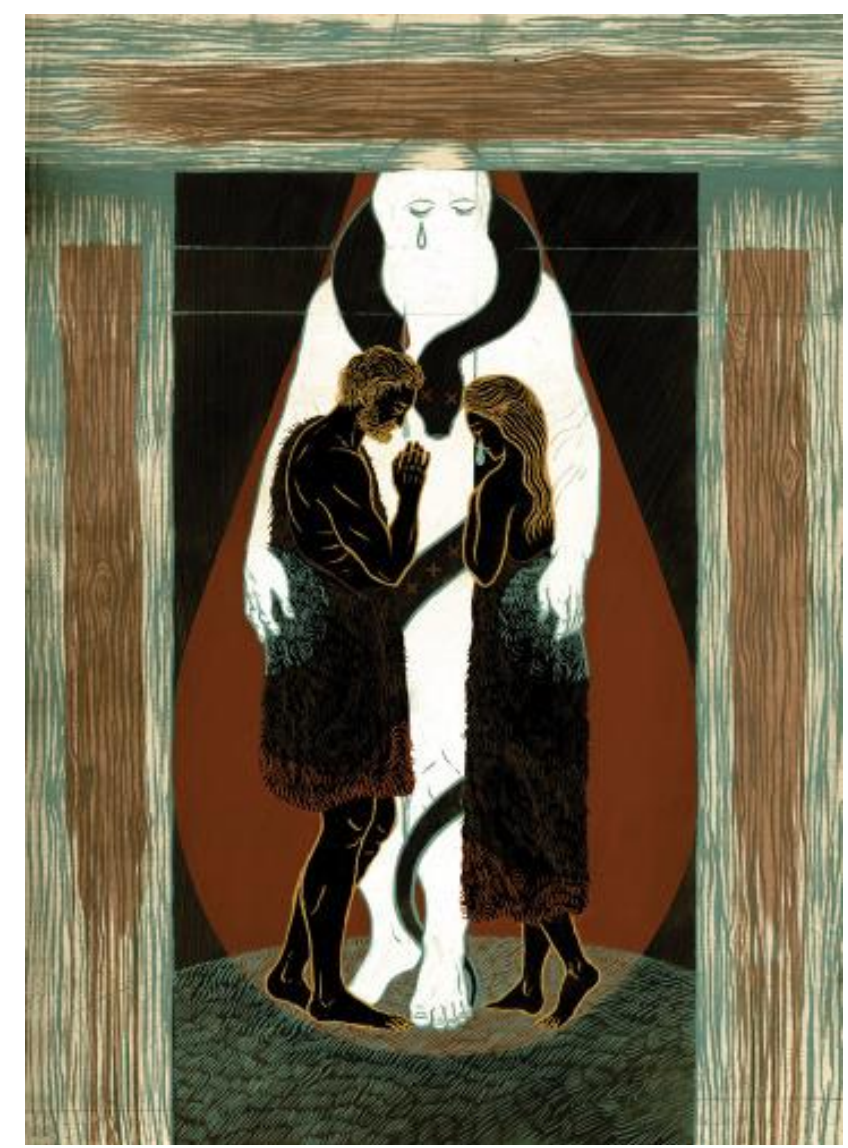

Figura 13 - Grace wold reign, Chris Koelle,2014, técnica mista.

Fonte: chriskoelle.com

Com o passar das décadas e a adesão cada vez maior, primeiramente da população mais humilde, e mais tarde se difundido entre as mais variadas camadas sociais, a fé protestante acabou por lançar seus esforços em direção a uma modificação efetiva de sua linguagem. Adotou estratégias artísticas como veículo às suas ações evangelísticas, e também, através de mídias variadas, modernizou-se para expandir sua doutrinação a um público mais jovem e acostumado a diferentes plataformas culturais. Visto que a arte é um instrumento poderoso para toda a miríade de questionamentos, sentimentos, pensamentos e reflexões provenientes da mente humana, ela obviamente não se isenta de carregar a doutrinação quando produzida com este intento. Fica evidente, portanto que a comunidade evangélica acaba por criar seu próprio segmento artístico, visando proporcionar não apenas o ato evangelístico de alcançar os nãoconvertidos, mas também se apoiando num discurso que destaca o fazer criativo como um ato de adoração ao seu Deus.

\section{CONCLUSÃO}

Conclui-se que o fazer criativo está relacionado de forma íntima à experiência religiosa por uma série de razões. Primeiramente, destaca-se o poder da imagem junto ao mundo espiritual, tanto como portadora da alma do fiel, ou como um instrumento necessário a determinado objetivo a ser alcançado com o auxílio do espiritual. Uma pintura na parede de uma caverna pode mover forças invisíveis no momento da caça, 
assim como uma imagem colossal pode proteger barcos em águas perigosas. A crença está "amarrada" ao objeto criado com as mais diversas habilidades artísticas, servindo como meio de contato com uma divindade pessoal e particular, ou como receptáculo à uma vontade catalisadora de eventos.

Também aponta-se que a obra artística serve como catalisadora para inspiração, evocando sentimentos de respeito e temor que servem tanto para fortalecer a fé do crente, quanto a testemunhar sobre o poder de determinada entidade ao espectador de diferente credo. Dentro deste princípio, existe a razão emocional, que encontra reflexo no efeito que a obra tem sobre o crente. Desde as iluminuras medievais, acessíveis apenas à porção mais abastada da população, passando pelas impactantes pinturas barrocas que praticamente "abriam" o céu sobre a cabeça dos fiéis e chegando às mídias contemporâneas, como quadrinhos e cinema; a fé encontra um meio de permanecer através de narrativas grandiosas que tocam o público e garantem sua difusão para a posteridade. Embora Arte e Igreja já tenham tomado caminhos separados, ambas continuam relacionadas, e numerosos artistas dedicam suas habilidades à criação com viés religioso.

Por fim, há o valor fundamental agregado a diferentes signos e linguagens, quando acompanhado da idéia de uma espiritualidade intrínseca ao objeto criado. Valese destacar o fazer artístico como forma de mover o fiel em direção à sua experiência religiosa, pautando-se profundamente na potência de estímulos sensoriais. Essa prática subsiste até os dias atuais, por mais que as mídias tenham se modernizado. O peso destas vivências encontra respaldo nas palavras de Dewey (2010):

\footnotetext{
Uma mesma palavra, "símbolo", é usada para designar expressões de pensamento abstrato, como na matemática, e coisas como uma bandeira ou um crucifixo, que incorporam um profundo valor social e o significado da fé histórica e do credo teológico. O incenso, os vitrais, o badalar de sinos invisíveis e os mantos bordados acompanham a abordagem do que é considerado divino. (DEWEY,2010, p.100)
}

Sendo assim, a Arte pode ser usada como uma ferramenta de amparo, que auxilia o fiel a seguir através de suas dificuldades tendo em mente um vislumbre do divino que o motiva à manter sua fé. Seja na forma de uma monumental estátua, ou de uma minúscula medalha, o valor jaz na idéia de um elo existente entre ambos; crente e crença. 


\section{REFERÊNCIAS}

BELL, Clive. Art. Londres: Chatto \& Windus, 1914.

BURKE, Peter. Cultura popular na Idade Moderna. 2 ed. São Paulo: Cia. Das Letras, 1999.

CAMPBELL, Joseph. As máscaras de Deus: mitologia. São Paulo: Palas Athena, 2010.

CUNHA, Magali do Nascimento. Explosão Gospel - Um Olhar das Ciências Humanas Sobre o Cenário Evangélico no Brasil. São Paulo: MAUAD, 2007.

DEWEY, John. Arte como experiência. São Paulo: Martins Fontes, 2010.

GOMBRICH, Hans Ernest. A História da Arte, 16.ed. Rio de Janeiro: Livros

SCHAEFFER, Francis. A Arte e a Bíblia, Minas Gerais: Editora Ultimato, 2010.

\section{Meios Eletrônicos Consultados:}

A Evolução da Arte e dos Rituais. Fonte: http://scienceblogs.com.br/marcoevolutivo/2008/08/30/a-evolucao-da-arte-e-dos-rituais/ Acessado em 20 de Dezembro de 2016.

Artes e Espiritualidade. Fonte: https://konkokyofloripa.wordpress.com/2015/01/17/arte-e-espiritualidade Acessado em 24 de Dezembro de 2016

A Arte e o Ritual. Fonte: historiabruno.blogspot.com.br/2013/01/a-arte-e-o-ritual.htm. Acessado em: 12 de Outubro de 2016. 